\title{
STUDI KEMAMPUAN TANAH MENYIMPAN AIR TERSEDIA DI SENTRA BAWANG PUTIH KECAMATAN PUJON, KABUPATEN MALANG
}

\section{Study of Water-Holding Capacity of Soils in Garlic Areas of Pujon District, Malang Regency}

\author{
Siti Khodijah* , Soemarno \\ Jurusan Tanah, Fakultas Pertanian, Universitas Brawijaya, Jl. Veteran 1 Malang, 65145 \\ *Penulis korespondensi: sitekkhodijah@gmail.com
}

\begin{abstract}
One of the essential soil resources for garlic cultivation is the soil available water content. The purposes of this study were to create $\mathrm{pF}$ curves in the garlic areas, to find out the available soil water content, and to find out the impact of pore distribution on available soil water in garlic areas in Pujon, Malang. Parameters observed were soil texture, soil bulk density, soil specific gravity, soil available water content, $\mathrm{pF}$ curve, distribution of soil pores and soil porosity. Results of the study showed that there was a specific $\mathrm{pF}$ curve at each observation point. Status distribution of soil available water content in garlic areas was high, medium and low. Furthermore, the pore distribution which includes macropores and mesopores was a factor that influenced the soil available water content. The result of this study expected to be able to give beneficial information that can be used as a reference in land management. Also, it is expected that the land management in the garlic areas, Pujon sub-district, Malang will take land mapping unit 2 as the land management to improve the garlic production.
\end{abstract}

Keywords: garlic plant, $p \mathrm{~F}$ curve, soil available water content, soil physical properties

\section{Pendahuluan}

Tanaman bawang putih (Allium sativum L.) merupakan salah satu komoditas pangan penting di Indonesia. Bawang putih diketahui dapatd igunakan sebagai bahan penyedap rasa, pakan, dan juga sebagai bahan pengobatan sehingga menjadikan komoditas ini memiliki tingkat konsumsi yang besar (Sholihin et al., 2016). Seiring dengan meningkatnya jumlah penduduk dari tahun ke tahun, kebutuhanakan bawang putih juga semakin meningkat.

Data Kementerian Pertanian (2017) menunjukkan bahwa konsumsi bawang putih masyarakat pada tahun 2016 mencapai 465.100 tnamun produksi hanya sekitar $21.150 \mathrm{t}$ sehingga terjadi deficit 443.950 t. Pada tahun 2017, konsumsi bawang putih mencapai $482.190 \mathrm{t}$ sedangkan produksi hanya $19.510 \mathrm{t}$ sehingga terjadi defisit $462.680 \mathrm{t}$ dengan luas lahan panen 2.146 ha dengan produktivitas $8,45 \mathrm{t} \mathrm{ha}^{-1}$. Hal ini menyebabkan pemerintah harus melakukan pengimporan bawang putih setiap tahunnya untuk memenuhi kebutuhan masyarakat.

Produksi bawang putih yang rendah disebabkan oleh luas lahan dan produktivitas hasil yang cukup rendah. Salah satu upaya yang dapat dilakukan untuk meningkatkan produksi tanaman bawang putih adalah dengan melakukan kegiatan ekstentifikasi. Upaya pemenuhan kebutuhan bawang putih di Indonesia terkonsentrasi di Pulau Jawa, khususnya Jawa Timur dan Jawa Tengah. Upaya tersebut telah dilakukan oleh Kementan BPTP Jawa Timur di tahun 2018 dengan melakukan perluasan areal penanaman bawang putih yang akan menjadi sentra bawang putih di Jawa Timur, antara lain di Pasuruan, 


\section{Jurnal Tanah dan Sumberdaya Lahan Vol 6 No 2 : 1405-1414, 2019 e-ISSN:2549-9793, doi: 10.21776/ub.jtsl.2019.006.2.21}

\author{
Probolinggo, Kecamatan Ngantang, dan \\ Kecamatan Pujon.
}

Sumberdaya alam yang sangat penting untuk kebutuhan tanaman adalah air. Air yang berada di dalam tanah merupakan air yang dimanfaatkan oleh tanaman (Doorenbos dan Pruitt, 1977). Sementara itu, tanaman bawang putih membutuhkan air yang cukup pada awal pertumbuhan hingga pembentukan umbi dan perkembangan umbinya (Pelter et al., 2004; Ayars, 2008). Kecukupan air pada awal tanam merupakan syarat yang mutlak dalam tercapainya pertumbuhan tanaman yang baik (Villalobos et al., 2004; Abyaneh et al., 2011). Kekurangan air pada awal pertumbuhan akan berpengaruh negative terhadap pertumbuhan dan hasil tanaman (Pelter et al., 2004; Kumar et al., 2007), karena hal ini dapat menghambat proses fotosintesis dan proses penyerapan unsur hara dari dalam tanah oleh akar tanaman (Bossie et al., 2009; Muis et al., 2013). Air yang tersedia di dalam tanah merupakan air yang digunakan oleh tanama nbawang (Kadayifci et al., 2005), yaitu air yang berada antara kapasitas lapangan dan titik layu permanen (Quirijnde, 2017). Selisih antara kadar air tanah pada kapasitas lapangan dan titik layu permanen disebut air tersedia (Marsha et al., 2014; Silva et al., 2014). Oleh karena itu, penelitian ini dilakukan untuk mengetahui sebaran kemampuan tanah menyimpan air tersedia dan mengetahui pengaruh sebaran pori terhadap air tersedia sehingga dapat dijadikan acuan untuk pengelolaan tanah tanaman bawang putih dalam jangka waktu ke depan di Kecamatan Pujon, Kabupaten Malang.

\section{Bahan dan Metode}

Penelitian ini dilakukan pada bulan September 2018 sampai dengan Januari 2019 di sentra bawang putih Kecamatan Pujon, Kabupaten Malang yang tersebar di lima desa yaitu Desa Pandesari, Pujon Lor, Madiredo, Sukomulyo dan Bendosari. Analisis tanah dilaksanakan di Laboratorium Fisika Tanah, Fakultas Pertanian, Universitas Brawijaya, Malang. Metode penelitian yang dilakukan adalah dengan metode survei yang terdiri dari tahap prasurvei, survei dan pascasurvei. Penentuan titik pengambilan sampel tanah dengan metode purposive sampling berdasarkan kriteria produksi tanaman bawang putih dan mempunyai aksesibilitas yang mudah dijangkau. Selanjutnya melakukan groundcheck wawancara dengan petani yang berupa kuisioner untuk mengetahui bagaimana pengelolaan bawang putih di masing-masing titik pengamatan.

Pengambilan sampe ltanah dilakukan pada kedalaman 0-30 cm (lapisan atas) dan kedalaman 30-60 cm (lapisan bawah). Terdapat 8 sampel tanah di setiap satu titik pengamatan. Variabel penelitian yang diamati pada penelitian ini beserta metode analisisnya adalah: a) tekstur tanah (metode pipet), b) berat isi tanah (metode silinder), c) berat jenis tanah (metode piknometer), d) porositas tanah (perhitungan menggunakan data berat isi dan berat jenis, 1$\mathrm{BI} / \mathrm{BJ}$ ), e) distribusi ukuran pori makro (kurva $\mathrm{pF}$, f) kadar air pada berbaga ipF yaitu $\mathrm{pF} 0$, $\mathrm{pF}$ 1, pF 2,5 dan pF 4,2 (Metode Sand Box, Kaolin Box dan Pressure Plate Apparatus) dan g) kadar air tersedia (perhitungan $\mathrm{pF} 2,5-\mathrm{pF}$ 4,2). Data hasil laboratorium selanjutnya dianalisis secara statistic menggunak ananalisis korelasi melalui SPSS versi 20.0 dan regresi melalui Microsoft Excel 2016 untuk mengetahui hubungan antar parameter yang diamati.

\section{Hasil dan Pembahasan}

\section{Tekstur tanah}

Perbandingan proporsi partikel pasir, debu dan liat pada masing-masing perlakuan disajikan pada Gambar 1.Hasil analisis menunjukkan bahwa tekstur tanah yang terbentuk pada SPL 1 lapisan atas dan lapisan bawah memiliki kelas tekstur lempung berdebu, SPL 2 lapisan atas memiliki kelas tekstur lempung berliat dan pada lapisan bawah memiliki kelas tekstur lempung, SPL 3 lapisan atas dan lapisan bawah memiliki kelas tekstur lempung, SPL 4 lapisan atas dan lapisan bawah memiliki kelas tekstur lempung berliat dan SPL 5 memiliki kelas tekstur lempung liat berdebu pada lapisan atas dan pada lapisan bawah memiliki kelas tekstur liat berdebu.

Secara umum proporsi pasir di lokasi penelitian berkisar antara 10-32\%, sedangkan untuk proporsi debu memiliki range yang lebih besar yaitu berkisar antara 39-58\% dan liat antara 15\%-50\%. Secara keseluruhan, kelima 


\section{Jurnal Tanah dan Sumberdaya Lahan Vol 6 No 2 : 1405-1414, 2019 e-ISSN:2549-9793, doi: 10.21776/ub.jtsl.2019.006.2.21}

SPL didominasi oleh kelas tekstur tanah lempung. Tanah yang bertekstur lempung sesuai dengan syarat budidaya tanaman bawang putih. Samadi (1999) menyatakan bahwa kondisi tanah yang paling sesuai untuk tanaman bawang putih yaitu tanah yang bertekstur lempung atau lempung berliat. Menurut Suleman et al. (2016) bahwa tanah yang bertekstur lempung memiliki kriteria tanah sehat.
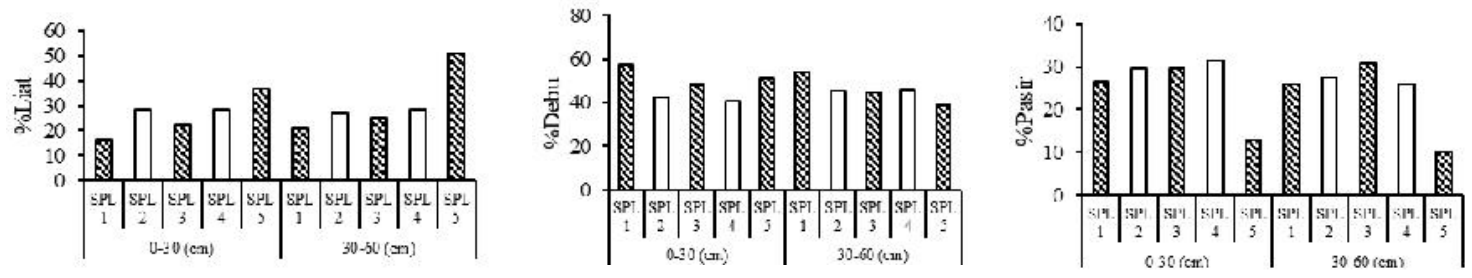

Gambar 1. Nilai fraksi tekstur tanah pada kedalaman 0-30 cm dan 30-60 cm

\section{Berat isi, berat jenis dan porositas}

Hasil analisis menunjukkan bahwa nilai berat isi tanah dari kelima SPL tergolong dalam kelas sedang (Tabel 1). Terdapat perbedaan nilai berat isi pada kelima SPL dikarenakan adanya perbedaan besarnya kandungan bahan organik dan tekstur tanah.Rata-rata berat isi tanah tertinggi dijumpai pada SPL $5\left(1,03 \mathrm{~g} \mathrm{~cm}^{-3}\right)$ dan kandungan bahan organic dengan nilai 3,82\% dan rata-rata berat isi terendah pada SPL 1 $\left(0,95 \mathrm{~g} \mathrm{~cm}^{-3}\right)$ dan kandungan bahan organik dengan nilai $0,173 \%$. Nilai berat isi meningkat disebabkan oleh rendahnya kandungan bahan organik. Hal ini sesuai dengan Yuwono dan Rosmarkam (2002) menjelaskan bahwa setiap lapisan tanah memiliki nilai berat isi yang bervariasi hal tersebut dipengaruhi oleh bahan organik tanah, tipe tanah dan tekstur tanah. Nita et al.(2014) juga mengungkapkan bahwa, tinggi atau rendahnya berat isi ditentukan oleh banyaknya pori dan padatan tanah.

Berat jenis partikel dari suatu tanah menunjukkan kerapatan dari partikel secara keseluruhan.Berat jenis tanah penting karena dengan adanya berat jenis dapat mengetahui porositas. Berat jenis, berat isi dan porositas digunakan untuk mengetahui kemampuan tanah menyimpan air tersedia. Tabel 1 menunjukkan bahwa nilai berat jenis tanah yang diambil di setiap titik pengamatan masih dalam kisaran $2 \mathrm{~g}$ $\mathrm{cm}^{-3}$. Porositas menunjukkan ruang kosong yang terdapat pada suatu volume tanah yang dapat diisi oleh air dan udara. Tabel 1 menunjukkan bahwa pada kelima SPL memiliki nilai porositas yang dikategorikan kedalam kelas sedang karena mempunyai nilai porositas $<63 \%$.

Nilai porositas tertinggi terdapat pada SPL 3 lapisan atas dengan nilai $60,19 \%$ dan nilai berat isi $0,96 \%$ dan nilai porositas terendah terdapat pada SPL 2 lapisan bawah dengan nilai $55,11 \%$ dan nilai berat isi $1,06 \%$. Hal ini dapat diketahui bahwa nilai berat isi berbanding terbalik dengan nilai porositas. Haryati (2014) menyatakan bahwa tanah dengan ruang pori total yang tinggi, seperti tanah liat, cenderung mempunyai berat isi lebih rendah. Sebaliknya, tanah dengan tekstur kasar, walaupun ukuran porinya lebih besar, namun total ruang porinya lebih kecil, mempunyai berat isi yang lebih tinggi.

\section{Distribusi ukuran pori}

Pori tanah terbagi menjadi pori mikro, pori meso dan pori makro yang kemudian seluruh jenis pori ini menunjukkan nilai ruang pori total.Berdasarkan nilai distribusi ukuran pori diatas dapat diketahui bahwa pori makro pada kelima SPL tergolong dalam kelas tinggi dengan nilai lebih dari $>15 \%$ (Tabel 1). Ratarata pori makro tertinggi terdapat pada SPL 2 lapisan bawah(29,25\%)dan pori makro terendah terdapat pada SPL 2 lapisan bawah $(18,99 \%)$. Rata-rata pori meso tertinggi terdapat pada SPL 2 lapisan bawah (19,88\%) dan pori meso terendah terdapat pada SPL 4 lapisan bawah $(9,06 \%)$. Adanya perbedaan jumlah pori tanah, baik pori makro, meso dan mikro pada kelima SPL diduga karena dipengaruhi oleh kelas tekstur tanah yang 


\section{Jurnal Tanah dan Sumberdaya Lahan Vol 6 No 2 : 1405-1414, 2019 e-ISSN:2549-9793, doi: 10.21776/ub.jtsl.2019.006.2.21}

berbeda. Pori mikro pada SPL 1 lapisan atas memiliki nilai $20,86 \%$ dan memiliki tekstur tanah lempung berdebu dengan kandungan liat sebesar 15,86\%. Pori mikro pada SPL 5 memiliki nilai 32,05\% dan tekstur tanah pada SPL 5 memiliki tekstur liat berdebu dengan kandungan liat sebesar 50,77\%. Oleh karena itu, dapat dinyatakan bahwa tekstur tanah mempengaruhi sebaran pori. Hasil-hasil penelitian para peneliti lain menunjukkan bahwa porositas tanah dan besarnya ruang pori tanah dipengaruhi oleh agregasi tanah, struktur tanah, dan tekstur tanah (Wang et al., 2016; Pires et al., 2017; Rabot et al., 2018).

\section{Kadar air tersedia}

Pengukuran kadar air tersedia didapatkan dari pengukuran kadar air volume pada kapasitas lapang $(\mathrm{pF} 2,5)$ dan titik layu permanen $(\mathrm{pF}$ 4,2). Hasil analisis laboratorium sampel tanah pada kelima SPL memiliki nilai kadar air tersedia(Tabel 1) yang bervariasi berdasarkan kedalaman tanah yang selanjutnya dicocokkan berdasarkan Laboratorium Fisika Jurusan Tanah Fakultas Pertanian Universitas Brawijaya (2006). Rata-rata kadar air tersedia tertinggi dijumpai pada SPL 2 (19,5\%) dan rata-rata kadar air tersediaterendahdijumpai pada SPL 4 (9,5\%).

Nilai kadar air tersedia tertinggi dapat dilihat pada SPL 2 (Tabel 1). Sebaran kadar air tersedia pada lapisan atas dan lapisan bawah di setiap SPL yaitu pada SPL 4 lapisan bawah nilai kadar air tersedia tergolong rendah sedangkan pada SPL 1, 2 dan SPL 3 nilai kadar air tersedia tergolong sedang (Gambar 2).Adanya perbedaan ini diduga karena adanya perbedaan tekstur, berat isi, porositas dan bahan organik di setiap SPL. Hal ini sesuai dengan Ayu et al. (2013) menyatakan bahwa perbedaan kondisi permukaan tanah, bahan organik, tekstur, struktur dan vegetasi merupakan faktor penyebab terjadinya perbedaan kapasitas menyimpan air. Semakin meningkatnya nilai porositas tanah maka bobot isi tanah akan semakin rendah, sehingga ruang pori yang dapat diisi oleh air juga semakin banyak (Keller dan Håkansson, 2010; Hong et al., 2013).

\section{Kurva pF}

Kurva karakteristik kadar air tanah atau kurva $\mathrm{pF}$ merupakan kurva yang dapat menggambarkan kondisi kadar air tanah pada berbagai hisapan matriks.Pada pF 2.5 di SPL 1, kadar air tanah lapisan atas adalah 38,5\% dan untuk lapisan bawah adalah 39,5\%. Pada $\mathrm{pF}$ 4.2, kadar air tanah lapisan atas adalah 21\% dan lapisan bawah adalah 25,5\%.

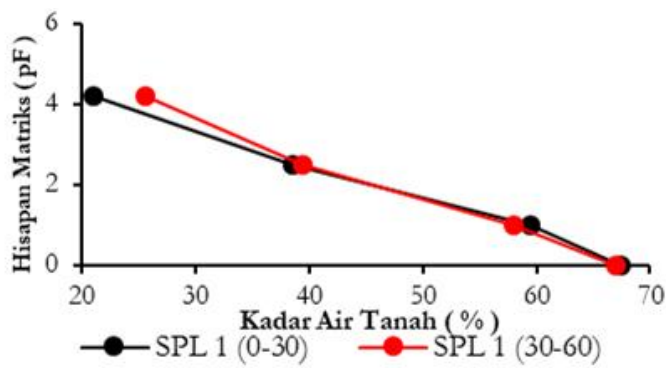

Gambar 2. Kurva pF berdasarkan kedalaman tanah pada SPL 1.

Pada pF 2.5 di SPL 2, kadar air tanah lapisan atas adalah 41\% dan lapisan bawah adalah 45\%. Pada $\mathrm{pF} 4.2$, kadar air tanah lapisan atas adalah $23 \%$ dan lapisan bawah adalah $25,5 \%$.

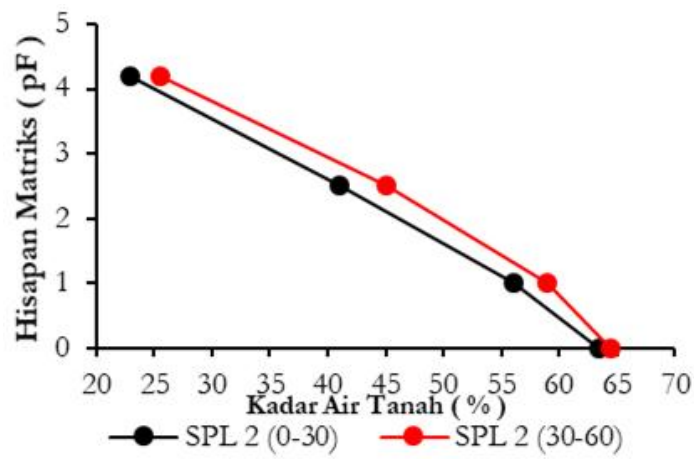

Gambar 3. Kurva pF berdasarkan kedalaman tanah pada SPL 2.

Pada pF 2.5 di SPL 3, kadar air tanah lapisan atas adalah 38\% dan untuk lapisan bawah adalah 42\%. Pada $\mathrm{pF}$ 4.2, kadar air tanah lapisan atas adalah 23,5\% dan untuk lapisan bawah adalah 23\%. Pada pF 2.5 di SPL 4 , kadar air tanah lapisan atas adalah 35,5\% dan lapisan bawah adalah 38,5\%. Pada $\mathrm{pF} 4.2$, kadar air tanah lapisan atas adalah 21\% dan untuk lapisan bawah adalah 29\%. Pada pF 2.5 di SPL 5, kadar air tanah lapisan atas adalah $39 \%$ dan untuk lapisan bawah adalah 43,5\%. 
Pada pF 4.2, kadar air tanah lapisan atas adalah $27 \%$ dan untuk lapisan bawah adalah $32 \%$.

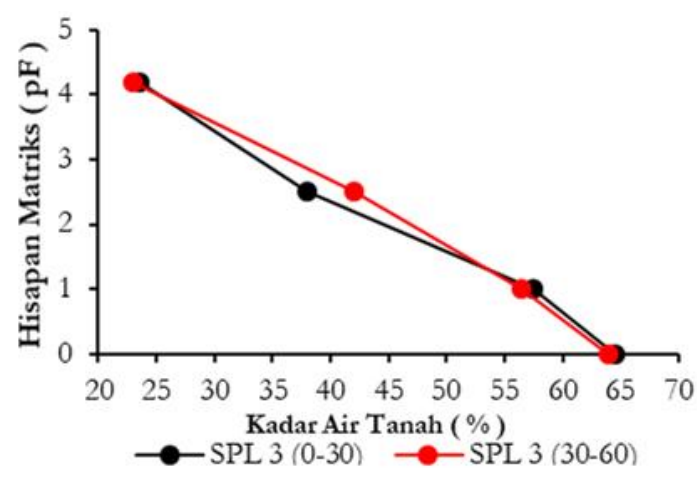

Gambar 4. Kurva pF berdasarkan kedalaman tanah pada SPL 3

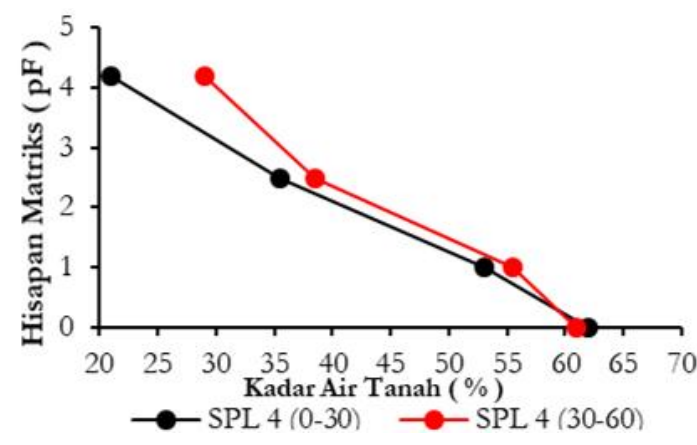

Gambar 5. Kurva pF berdasarkan kedalaman tanah pada SPL 4

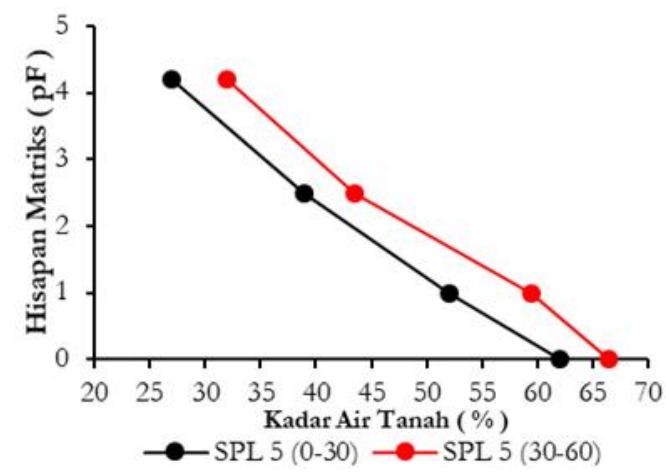

Gambar 6. Kurva pF berdasarkan kedalaman tanah pada SPL 5.

Secara keseluruhan, kadar air pada lapisan bawah lebih tinggi daripada kadar air pada lapisan atas. Hal tersebut diduga karenaair tanah di lapisan tersebut telah bergerak ke lapisan yang lebih dalam sebagai akibat kadar air lapisan atasnya telah mencapai kapasitas lapang terlebih dahulu, adanya perbedaan tekstur, bahan organik, berat isi dan porositas pada kedalaman tersebut. Pernyataan ini didukung oleh pendapat Junedi (2014), bahan organik dapat menyerap air sampai enam kali beratnya sendiri sehingga dengan semakin tinggi kandungan bahan organik dalam tanah maka akan berakibat meningkatnya kadar air tanah.

Tabel 1. Karakteristik sifat fisika tanah

\begin{tabular}{ccccccccc}
\hline SPL & $\begin{array}{c}\text { Kedalaman } \\
\mathbf{( c m )}\end{array}$ & $\begin{array}{c}\text { BI } \\
\mathbf{( \% )}\end{array}$ & $\begin{array}{c}\text { BJ } \\
\mathbf{( \% )}\end{array}$ & $\begin{array}{c}\text { Makro } \\
\mathbf{( \% )}\end{array}$ & $\begin{array}{c}\text { Meso } \\
\mathbf{( \% )}\end{array}$ & $\begin{array}{c}\text { Mikro } \\
\mathbf{( \% )}\end{array}$ & $\begin{array}{c}\text { Porositas } \\
\mathbf{( \% )}\end{array}$ & $\begin{array}{c}\text { Air } \\
\text { Tersedia } \\
\mathbf{( \% )}\end{array}$ \\
\hline \multirow{2}{*}{1} & $0-30$ & 0,96 & 2,37 & 29,25 & 17,61 & 20,86 & 59,77 & 17,5 \\
& $30-60$ & 0,95 & 2,25 & 27,75 & 13,76 & 25,57 & 58,06 & 14 \\
2 & $0-30$ & 1,1 & 2,48 & 23,02 & 18,21 & 22,62 & 55,81 & 18 \\
& $30-60$ & 1,06 & 2,34 & 18,99 & 19,88 & 25,27 & 55,11 & 19,5 \\
3 & $0-30$ & 0,96 & 2,41 & 26,57 & 13,89 & 23,8 & 60,19 & 14,5 \\
\multirow{2}{*}{4} & $30-60$ & 1 & 2,23 & 22,08 & 19,29 & 22,69 & 55,39 & 19 \\
& $0-30$ & 1 & 2,25 & 26,46 & 14,8 & 20,98 & 55,46 & 14,5 \\
& $30-60$ & 0,98 & 2,39 & 22,69 & 9,06 & 29,19 & 59,39 & 9,5 \\
& $0-30$ & 0,98 & 2,18 & 22,96 & 11,85 & 27,03 & 55,11 & 12 \\
& $30-60$ & 1,03 & 1,03 & 23,27 & 11,32 & 32,05 & 55,82 & 11,5 \\
\hline
\end{tabular}




\section{Jurnal Tanah dan Sumberdaya Lahan Vol 6 No 2 : 1405-1414, 2019 e-ISSN:2549-9793, doi: 10.21776/ub.jtsl.2019.006.2.21}

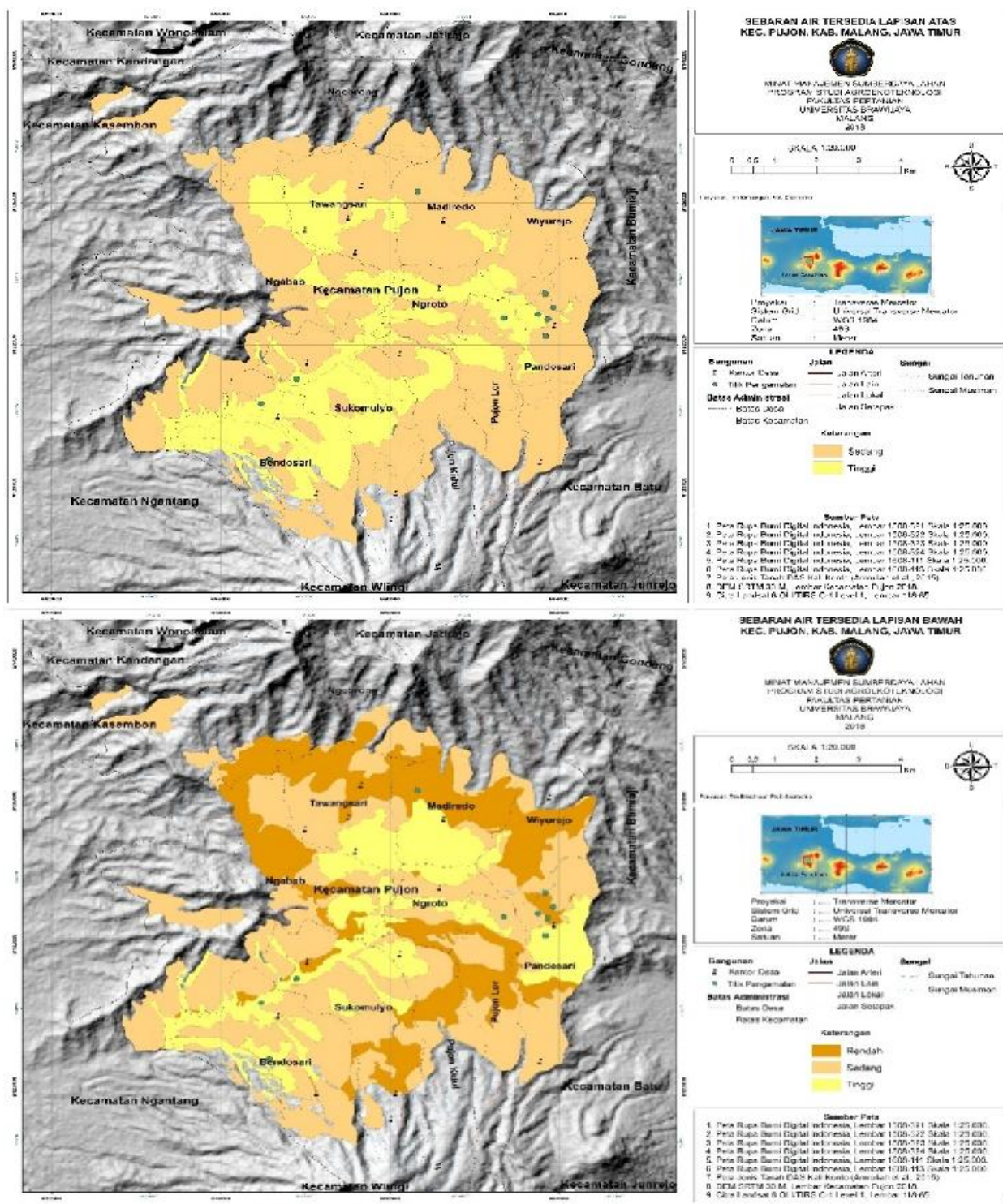

Gambar 7. Peta sebaran air tersedia lapisan atas dan lapisan bawah.

Hal ini didukung oleh penelitian Jambak (2017) yang menyatakan bahwa pada lahan tegalan adalah lahan dengan kadar air kapasitas lapang yang paling rendah, dengan nilai yang meningkat dengan semakin dalamnya lapisan tanah pada lahan tersebut dan atau dapat juga disebabkan karena air di lapisan atas terlebih dahulu digunakan tanaman untuk proses evapotranspirasi.Menurut Rosyidah dan Wirosoedarmo (2013) nilai berat isi yang tinggi mengakibatkan tanah akan lebih sulit meneruskan air sehingga pergerakan air menjadi terhambat. Berat isi yang tinggi akan terjadi penurunan pori tanah sehingga kemampuan menahan air menjadi kecil atau kadar air tanah tersebut akan semakin berkurang.

\section{Produksi bawang putih di Kecamatan Pujon}

Produksi yang paling tinggi di kelima SPL berada pada SPL 2 di Desa Bendosari dengan luas lahan $750 \mathrm{~m}^{2}$ dan jarak tanam 10x15 cm mampu menghasilkan produksi sebesar 7,3 t $\mathrm{ha}^{-1}$. Varietas yang digunakan adalah Lumbu Kuning dan Lumbu Hijau. Pengairan di lahan tersebut menggunakan sistem irigasi. Pengolahan lahan yang dilakukan pada petani 


\section{Jurnal Tanah dan Sumberdaya Lahan Vol 6 No 2 : 1405-1414, 2019 e-ISSN:2549-9793, doi: 10.21776/ub.jtsl.2019.006.2.21}

yaitu pengolahan lahan dengan membuat guludan. Tinggi bedengan pada lahan tersebut yaitu $0,2 \mathrm{~m}$, panjang bedengan yaitu $2 \mathrm{~m}$, lebar bedengan yaitu $1 \mathrm{~m}$ dan parit bedengan yaitu 0,2 m. Produksi sebesar 7,33 t ha-1. dikategorikan tinggi karena hal ini sesuai dengan Wibowo (2006) yang menyatakan bahwa bawang putih varietas Lumbu Kuning dan Lumbu Hijau dapat mencapai hasil produksi maksimal sebesar 7-9 ton umbi per hektar.

Produksi yang paling rendah di kelima SPL berada pada SPL 3 di Desa Bendosari dengan luas lahan $750 \mathrm{~m}^{2}$ dan jarak tanam 10x15 cm menghasilkan produksi sebesar 0,33 t ha-1 ${ }^{-1}$ Di SPL 3 Desa Bendosari menggunakan varietas Lumbu Kuning dan varietas impor yaitu Green Black Leaf. Pengairan di lahan tersebut menggunakan sistem tadah hujan. Pengolahan lahan yang dilakukan pada petani yaitu pengolahan lahan dengan membuat guludan. Adapun tinggi bedengan pada lahan tersebut yaitu $0,3 \mathrm{~m}$, panjang bedengan yaitu 8 $\mathrm{m}$, lebar bedengan yaitu $1 \mathrm{~m}$ dan parit bedengan yaitu $0,25 \mathrm{~m}$.

\section{Hubungan sifat fisik tanah}

Hasil analisis korelasi antar parameter pengamatan sifat fisik tanah berdasarkan kedalaman tanah yaitu lapisan atas $0-30 \mathrm{~cm}$ dan lapisan bawah 30-60 cm menunjukkan ada atau tidaknya hubungan antar parameter dan bagaimana keeratan hubungan yang terjadi. Perubahan berat isi memiliki hubungan negatif yang sangat nyata secara statistic dengan porositas pada lapisan atas dan lapisan bawah(r $=-0.76)$ dan $(\mathrm{r}=-0.90)$. Korelasi tersebut menunjukkan bahwa semakin meningkat berat isi maka terjadi penurunan terhadap porositas. Hal tersebut terjadi karena apabila kondisi berat isi tingg imaka pemadatan juga tinggi yang mengakibatkan ruang pori menjadi sedikit. Hal ini sesuai dengan Hillel (1980) yang menyatakan semakin meningkatnya berat isi tanah maka nilai porositas akan semakin menurun dan sebaliknya jika berat isi tanah menurun maka porositas tanah akan meningkat. Berat isi tanah dapat berkurang jika bahan organic tanah tinggi. Menurut Adimihardja et al. (1999) menyatakan bahwa pemberian berbagai jenis dan takaran pupuk kendang atau bahan organic dapat memperbaiki sifat fisika tanah, yaitu menurunkan bobot isi tanah serta meningkatkan porositas tanah.

Kadar air pada pF 0 merupakan jumlah ruang pori yang terdapat di dalam tanah. Besarnya kadar air pada $\mathrm{pF} 0$ erat kaitannya dengan kadar air yang tersedia dalam tanah. Terdapat hubungan positif antara kadar air pada $\mathrm{pF} 0$ terhadap kadar air tersedia ( $\mathrm{r}=$ 0,27). Artinya kedua parameter tersebut berbanding lurus, apabila kadar air pada $\mathrm{pF} 0$ meningkat maka kadar air tersedia akan meningkat dan sebaliknya. Air tersedia memiliki hubungan positif yang sangat nyata dengan pori meso $(r=0.99)$. Sedangkan air tersedia memiliki hubungan negatif yang nyata dengan pori mikro $(\mathrm{r}=-0,66)$. Air tersedia meningkat seiring penurunan pori makro dan pori mikro. Penurunan pori ini menyebabkan peningkatan pori meso. Pori meso merupakan pori tempat air tersedia. Sehingga peningkatan pori meso menyebabkan peningkatan air tersedia pada kedalaman tanah 0-30 cm dan 30$60 \mathrm{~cm}$. Hal ini sesuai dengan Hardjowigeno (2003) yang menyatakan bahwa pori-pori tanah dapat dibedakan menjadi pori-pori kasar (makro) dan pori-pori halus (mikro). Pori-pori kasar berisi udara atau air gravitasi (air yang mudah hilang karena adanya gaya gravitasi), sedangkan pori-pori halus berisi air kapiler atau udara. Tanah yang mengandung banyak pori makro sulit untuk menahan air, sedangkan tanah dengan kandungan pori mikro dengan jumlah banyak merupakan pori bagi drainase lambat. Tanah yang mengandung banyak pori mikro maka drainasenya sangat buruk. Pori dalam tanah menentukan kandungan air dan udara di dalam tanah serta menentukan perbandingan pengelolaan air yang baik.

\section{Hubungan sebaran pori tanah dengan kadar air tersedia}

Hasil analisis korelasi antara sebaran pori dengan air tersedia pada kedalaman 0-30 cm menunjukkan nilai korelasi yaitu $\mathrm{r}=-0,47$ pada pori makro, pori meso menunjukkan nilai korelasi yaitu $\mathrm{r}=0,99$, dan pori mikro menunjukkan nilai korelasi yaitu $r=-0,66$. Hubungan pori mikro dan kadar air tersedia dapat dilihat pada garis linier $y=-0.9906 x+$ 41.402 dengan $\mathrm{x}$ adalah pori mikro dan $\mathrm{y}$ adalah kadar air tersedia dengan nilai $\mathrm{R}^{2}=$ 


\section{Jurnal Tanah dan Sumberdaya Lahan Vol 6 No 2 : 1405-1414, 2019 e-ISSN:2549-9793, doi: 10.21776/ub.jtsl.2019.006.2.21}

0,6673 dengan persentase 66\%. Dengan demikian, setiap peningkatan $1 \%$ pori mikro akan menurunkan kadar air tersedia sebesar $0,9906 \%$.

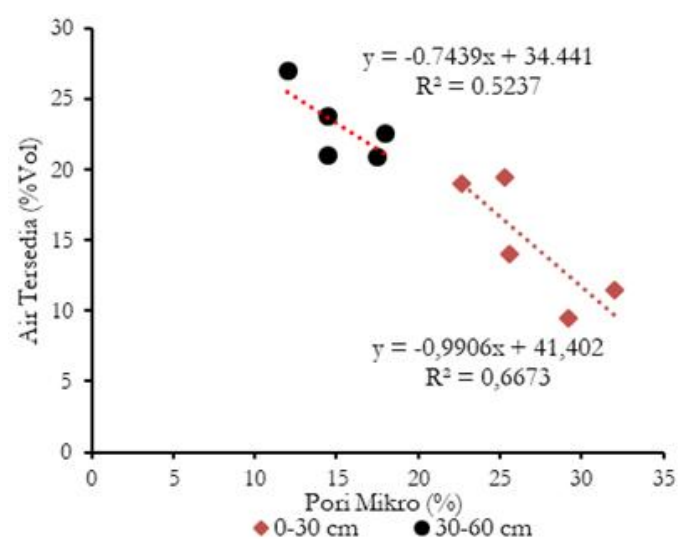

Gambar 8. Hubungan pori mikro terhadap kadar air tersedia pada kedalaman 0-30 cm dan $30-60 \mathrm{~cm}$.

Hasil analisis korelasi antara sebaran pori dengan air tersedia pada kedalaman 30-60 cm menunjukkan nilai korelasi yaitu $(\mathrm{r}=-0,26)$ pada pori makro, pori meso menunjukkan nilai korelasi yaitu $(\mathrm{r}=0,99)$, dan pori mikro menunjukkan nilai korelasi yaitu $(\mathrm{r}=-0,52)$. Hubungan pori mikro dengan air tersedia memiliki nilai yang negatif atau berbanding terbalik artinya semakin tinggi pori mikro maka kadar air tersedia semakin menurun. Hubungan pori mikro dan kadar air tersedia dapat dilihat pada garis linier $y=-0.7439 x+34.441$ dengan $\mathrm{x}$ adalah pori mikro dan y adalah kadar air tersedia dengan nilai $\mathrm{R}^{2}=0,5237$ dengan persentase $52 \%$. Dengan demikian, setiap peningkatan $1 \%$ pori mikro akan menurunkan kadar air tersedia sebesar 0,5227\%.

Menurut Sudaryono (2001) dalam penelitiannya menunjukkan bahwa semakin banyak ruang pori mikro yang terbentuk maka akan mempunyai daya simpan air yang semakin meningkat, kemudian air tanah tersebut akan mengisi ruang-ruang pori tanah, biasanya ruang pori-pori tanah yang terisi air adalah pori makro (Beven dan Germann, 1982; Amer, 2002). Pori meso dan mikro di dalam tanah adalah sebagai tempat air yang diikat oleh permukaan matriks tanah setelah hilangnya air gravitasi (Niemeyer dan Machulla. 1999; Wang dan Wang, 2007). Air yang berada pada kondisi ini termasuk air kapiler yang merupakan air tersedia bagi tanaman (Lu dan Likos, 2004; Amer, 2012).

\section{Hubungan sifat fisik tanah dengan produksi}

Berdasarkan analisis korelasi sederhana menunjukkan bahwa hubungan yang paling kuat dari sifat fisik tanah dengan produksi adalah kadar air pada pF 2,5, dan pori meso. Hasil analisis korelasi antara kadar air pada $\mathrm{pF}$ 2,5 dengan produksi menunjukkan korelasi yang positif secara statistik $(\mathrm{r}=0.36)$ artinya kadar air pada $\mathrm{pF} 2,5$ berbanding lurus dengan produksi. Apabila semakin tinggi nilai kadar air pada kapasitas lapangan ( $\mathrm{pF}$ 2,5) maka produksi akans emakin meningkat. Hasil analisis korelasi antara pori meso dengan produksi menunjukkan korelasi yang positif secara statistik $(\mathrm{r}=0.31)$ Hal ini dapat dinyatakan bahwa jika kebutuhan air tanaman tercukupi maka produksi akan semakin meningkat. Kondisi kesuburan tanah pada suatu lahan dicerminkan oleh jumlah air tersedia bagi tanaman (Metwally, 2011; Zheng et al., 2013).

Berdasarkan data hasil analisis laboratorium kadar air tersedia pada tanah yang telah dijelaskan sebelumnya, dapat diketahui bahwa pada SPL 2, Desa Pandesari dan Desa Sukomulyo memiliki nilai kadar air tertinggi yaitu $19,5 \%$ dan $18 \%$ dan memiliki tekstur tanah pada lapisan atas yaitu lempung berliat dan tekstur tanah pada lapisan bawah yaitu lempung. Oleh karena itu, tekstur tanah dan nilai kadar air tersedia diketahui mampu mempengaruhi produksi bawangputih. Apabila kadar air tersedia meningkat maka produksi bawang putih juga semakin meningkat. Riwandi (2011) menyatakan bahwa tekstur tanah yang ideal adalah tanah mengandung proporsional liat, debu, dan pasir sehingga terbentuk tekstur lempung (loamy soil).

Pengelolaan tanah yang dilakukan pada kelima SPL yaitu pengelolaan tanah dalam pembuatan guludan dan parit. Pengelolaan tanah dengan membuat guludan sesuai dengan syarat budidaya tanaman bawang putih agar menghasilkan tanah yang gembur. Tinggi, panjang, lebar bedengan juga mempengaruhi pertumbuhan dan hasil tanaman. Hal ini sesuai dengan penelitian Holish et al. (2014) yang 


\section{Jurnal Tanah dan Sumberdaya Lahan Vol 6 No 2 : 1405-1414, 2019 e-ISSN:2549-9793, doi: 10.21776/ub.jtsl.2019.006.2.21}

menyatakan bahwa perlakuan tinggi bedengan mempengaruhi tanaman bawang merah pada umur 42 HST dengan perlakuan tinggi bedengan $40 \mathrm{~cm}$ menghasilkan bobot basah per tanaman dan bobot basah per petak yang tinggi disbanding perlakuan tinggi bedengan $50 \mathrm{~cm}$ dan perlakuan tinggi bedengan $30 \mathrm{~cm}$. Maka dari itu, hal yang dapat diupayakan untuk meningkatkan produksi bawanga dalah pengolahan tanah dengan "system ridge tillage", yaitu pembuatan bedengan atau guludan dengan parit yang cukup dalam (Dina, 2016; Tayel et al.,2017).

\section{Kesimpulan}

Kurva pF yang spesifik ditemukan di setiap lokasi pengamatan di sentra produksi tanaman bawang putih Kecamatan Pujon, Kabupaten Malang. Status air tersedia pada lapisan tanah atas di SPL 1 dan SPL 2 tergolong "tinggi" sedangkan pada SPL 3, 4, dan 5 tergolong "sedang". Status air tersedia pada lapisan tanah-bawah di SPL 2 dan SPL 3 tergolong "tinggi" sedangkan di SPL 1 dan SPL 5 tergolong "sedang" dan di SPL 4 tergolong "rendah". Air tersedia dipengaruhi oleh sebaran pori, yaitu pori mikro dan pori meso

\section{Daftar Pustaka}

Abyaneh, H.Z., Varkeshi, M.B., Ghasemi, A., Marofi, S. and Chayjan, R.A. 2011. Determination of water requirement, single and dual crop coefficient of garlic (Allium sativum) in the cold semi-arid climate, AJCS 5(8):1050-1054.

Adimihardja, A., Juarsah, I. dan Kurnia, U. 1999. Pengaruh penggunaan berbagai jenis dan takaran pupuk kandang terhadap produktivitas tanah ultisol terdegradasi di Desa Batin, Jambi. Prosiding Seminar Nasional Sumber Daya Tanah, Iklim, dan Pupuk. Buku II. 6-8 Desember 1999. Pusat Penelitian Tanah dan Agroklimat, Bogor. pp 303-319.

Amer, A.M.M 2002. Drainable and water-filled pores as related to water storage and conductivity in agricultural soils of the Nile Delta. Verh. Internationale Vereinigung für Theoretische und Angewandte Limnologie: Verhandlungen

Amer, A.M.M. 2012. Water flow and conductivity into capillary and non-capillary pores of soils. Journal of Soil Science and Plant Nutrition 12 (1): 99-112.
Ayars, J.E. 2008. Water Requirement of Irrigated Garlic. American Society of Agricultural and Biological Engineers 51(5): 1683-1688.

Ayu, I.W., Prijono, S. dan Soemarno. 2013. Evaluasi Ketersediaan Air Tanah Lahan Kering di Kecamatan Unter Iwes, Sumbawa Besar. J-PAL. 4(1):18-25.

Beven, K. And Germann, P. 1982. Macropores and water flow in soils. Water Resource Research 18: 1311-1325.

Bossie, M., Tilahum, K. and Hordofa, T. 2009. Crop coefficient and evapotranspiration of onion at Awash Melkassa, Central Rift Valley of Ethiopia. Irrigation and Drainage Systems 23:110.

Dina, S. 2016. Design of a combined machine for seedbed preparation for onion. M.Sc. Thesis, Department of Agriculture Engineering, Faculty of Agriculture, Cairo University, Egypt.

Doorenbos, J. and Pruitt, W.O. 1977. Crop requirements. FAO Irrigation and Drainage Paper No. 24. Rome, Italy: Food and Agriculture Organization of the United Nations.

Hardjowigeno, S. 2003. Klasifikasi Tanah dan Pedogenesis. Akademika Pressindo. Jakarta. pp 6-10.

Haryati, U. 2014. Karakteristik fisik tanah kawasan budidaya sayuran dataran tinggi, hubungannya dengan strategi pengelolaan lahan. Jurnal Sumberdaya Lahan 8(2):125-138.

Hillel, D. 1980. Fundamental of Soil Physics. Academic Press Inc. London.

Holish., Murniyanto, E. dan Wasonowati, C. 2014. Pengaruh tinggi bedengan pada dua varietas lokal bawang merah (Allium ascalonicum L.). Jurnal Agrovigor 7(2):84-89.

Hong, S.Y., Minasny, B., Han, K.H., Kim, Y. and Lee, K. 2013. Predicting and mapping soil available water capacity in Korea. Peer Journal 1: e71.

Jambak, M.K., Baskoro, D.P. dan Wahjunie, E.D. 2017. Karakteristik sifat fisik tanah pada sistem pengolahan tanah konservasi (Studi Kasus: Kebun Percobaan Cikabayan). Buletin Tanah dan Lahan 1(1):44-50.

Junedi, H. 2014. Pengaruh Ara Sungsang (Asystasia gangetica (L.) T. Anders.) Terhadap Kadar Air Tersedia dan Hasil Kacang Tanah pada Ultisol. Prosiding Seminar Nasional Lahan Suboptimal, Palembang 26-27 September 2014. Hal. 400405.

Kadayifci, A., Tuylu, G.I., Ucar, Y. and Cakmak, B. 2005. Crop water use of onion (Allium cepa L.) in Turkey. Agricultural Water Management 72 (1):59-68.

Keller,T. and Håkansson, I. 2010. Estimation of reference bulk density from soil particle size 


\section{Jurnal Tanah dan Sumberdaya Lahan Vol 6 No 2 : 1405-1414, 2019 e-ISSN:2549-9793, doi: 10.21776/ub.jtsl.2019.006.2.21}

distribution and soil organic matter content. Geoderma 154: 398-406

Kementerian Pertanian. 2016. Statistik Produksi Komoditas Bawang Putih. Pusat Data dan Sistem Informasi Pertanian. Sekretariat Jenderal Kementrian Pertanian. Jakarta.

Kumar, S., Imtiyaz, M., Kumar, A. and Singh, R. 2007. Response of onion (Allium cepa L.) to different levels of irrigation water. Agricultural Water Management 89(1-2): 161-166.

Laboratorium Fisika Tanah. 2006. Instruksi Kerja. Pelaksanaan Analisis Tanah dan Pengolahan Data. Malang. Jurusan Tanah, Fakultas Pertanian. Universitas Brawijaya.

Lu, N. and Likos, W.J. 2004. Rate of capillary rise in soil. Journal of Geotechnical and Geoenvironmental Engineering 130(6): 646650.

Marsha, D.N., Aini, N. dan Sumarni, T. 2014. Pengaruh frekuensi dan volume pemberian air pada pertumbuhan tanaman Crotalaria mucronata Desv. Jurnal Produksi Tanaman 2:673-678.

Metwally, A.K. 2011. Effect of water supply on vegetative growth and yield characteristics in onion (Allium Cepa L.). Australian Journal of Basic and Applied Sciences 5(12): 3016-3023.

Muis, A., Indradewa, D. dan Widada, J. 2013. Pengaruh inokulasi mikoriza arbuskula terhadap pertumbuhan dan hasil kedelai (Glycine max (L.) Merrill) pada berbagai interval penyiraman. Jurnal Vegetalika 2(2):7-20.

Niemeyer, J. and Machulla, G. 1999. Description of soil pore systems accessible for water by fractal dimensions. Physica A: Statistical Mechanics and its Applications 266(1-4): 203-208.

Nita, I. 2014. Kajian lengas tersedia pada toposekuen lereng utara G. Kawi Kabupaten Malang Jawa Timur. Jurnal Tanah dan Sumberdaya Lahan 1 (2):53-60.

Pelter, G.Q., Mittelstadt, R., Leib, B.G. and Redulla, C.A. 2004. Effects of water stress at specific growth stages on onion bulb yield and quality. Agricultural Water Management 68(2): $107-$ 115.

Pires, L.F., Borges, J.A.R., Rosa, J.A., Cooper, M., Heck, R.J., Passoni, S. and Roque, W.L. 2017. Soil structure changes induced by tillage systems. Soil and Tillage Research, 165: 66-79.

Quirijnde, J. van Lier. 2017. Field capacity, a valid upper limit of crop availability water ? Agricultural Water Management 193: 214-220.

Rabot, E., Wiesmeier, M., Schlüter, L. and Vogel, H.J. 2018. Soil structure as an indicator of soil functions: A review. Geoderma, 314: 122-137.

Riwandi. 2011. Metode Cepat Penilaian Kesehatan Tanah Dengan Indikator Kinerja Tanah. Prosiding Seminar Nasional dan Rapat Tahunan
Dekan Bidang Ilmu-Ilmu Pertanian Tanggal 23 - 25 Mei 2011. Palembang. pp 295-315.

Rosyidah, E. dan Wirosoedarmo, R. 2013. Pengaruh Sifat Fisik Tanah Pada Konduktivitas Hidrolik Jenuh Di 5 Penggunaan Lahan (Studi Kasus Di Kelurahan Sumbersari Malang), 9:33-36.

Samadi, B. 1999. Usaha Tani Bawang Putih. Kanisius. Yogyakarta. pp 25-27.

Sholihin, Y., Suminar, E., Rizky, W.H. dan Pitaloka, G.G. 2016. Pertumbuhan eksplan meristem bawang putih (Allium sativum L.) kultivar Tawangmangu pada berbagai komposisi kinetin dan GA3 in vitro. Jurnal Kultivasi. 15(3):176 177.

Silva, B.M., Da Silva,É.A., De Oliveira,G.C., Ferreira, M.M. and Serafim, M.E. 2014. Plantavailable soil water capacity: estimation methods and implications. The Revista Brasileira de Ciência do Solo 38: 464-475.

Sudaryono. 2001. Pengaruh pemberian bahan pengkondisi tanah terhadap sifat fisik dan kimia tanah pada lahan marginal berpasir. Jurnal Teknologi Lingkungan 2(1):300-309.

Suleman, S., Rajamuddin, U.A. dan Isrun. 2016. Penilaian kualitas tanah pada beberapa tipe penggunaan lahan di Kecamatan Sigi Biromaru, Kabupaten Sigi. Jurnal Agrotekbis 4(6):712-718.

Tayel, M.Y., Pibars, S.K. and Salama, D.S. 2017. Effect of new tillage system and soil moisture content on some onion engineering properties. International Journal of Agricultural Research 12: 156-159.

Villalobos, F.J., Testi, L. and Orgaz, F.R. 2004. Evapotranspiration and crop coefficients of irrigated garlic in a semi-arid climate. Agrultural Water Managemenet Journal 64(3): 233-249.

Wang, J., Yang, W., Yu, B., Li, Z., Cai, C. and Ma, R. 2016. Estimating the influence of related soil properties on macro- and micro-aggregate stability in ultisols of south-central China. Catena 137: 545-553.

Wang, X. and Wang, L.B. 2007. Dynamic analysis of a water-soil-pore water coupling system. Computers \& Structures 85(11-14): 1020-1031

Wibowo, S. 2006. Budidaya Bawang Putih, Merah, dan Bombay. Penebar Swadaya. Jakarta. pp 1723.

Yuwono, N.W. dan Rosmarkam. 2002. Ilmu Kesuburan Tanah. Kanisius. Yogyakarta. pp 35.

Zheng, J., Huang, G., Wang, J., Huang, Q., Pereira, L.S., Xu, X. and Liu, H. 2013. Effects of water deficits on growth, yield and water productivity of drip-irrigated onion (Allium cepa L.) in an arid region of Northwest China. Irrigation Science 31: 995-1008. 